\title{
Ryanodine Receptor Channelopathies: The New Kid in the Arrhythmia Neighborhood
}

\author{
María Fernández-Velasco스, Ana María Gómez², \\ Jean-Pierre Benitah ${ }^{2}$ and Patricia $\mathrm{Neco}^{2}$ \\ ${ }^{1}$ Instituto de Investigacion Hospital La Paz, IdiPAZ, Madrid \\ 2Inserm, Univ. Paris-Sud 11, IFR141, Labex Lermit, Châtenay-Malabry, \\ ${ }^{1}$ Spain \\ ${ }^{2}$ France
}

\section{Introduction}

Cardiac arrhythmia is a major mortality cause in both acquired and inherited cardiomyopathy, accounting for more than 750.000 deaths per year $(\sim 0.1 \%$ of total recorded deaths) in Europe and the USA (Priori SG, 2002). The 2008 WHO rapport has foreseen that cardiovascular disease will be the world leading death cause in the near future, surpassing infectious diseases.

Some of these cardiac diseases are acquired as cardiac hypertrophy, which develops as an adaptation of the heart to diseases that challenge the heart work chronically. Cardiac hypertrophy often degenerates in heart failure (HF), the final outcome of most cardiovascular diseases. Chronic HF prevalence is increasing in western countries, with only $25 \%$ of men and $38 \%$ of women surviving 5 years after the onset of clinical signs. Quality of life is hampered by the reduced pump function, which can also lead to death. However, half of deceases in HF patients are sudden due to cardiac arrhythmia. During cardiac pathology, altered activity of the cardiac, type 2, ryanodine receptor (RyR2) may generate arrhythmia and sudden death. This risk is high in HF where there is a profound remodeling of $\mathrm{Ca}^{2+}$ cycling, and alterations in transmembrane $\mathrm{Ca}^{2+}$ influx, $\mathrm{Ca}^{2+}$ release or/and sarcoplasmic reticulum (SR) $\mathrm{Ca}^{2+}-$ load underlie systolic dysfunction (Gómez et al., 1997; Bénitah JP, 2002). Thus, when dealing with HF and poor cardiac outcomes, it is a need to better understand the mechanisms of cardiac arrhythmia in order to efficiently treat these patients. However, a large number of inherited arrhythmogenic syndromes that cause sudden death have been characterised. Some are associated with structural heart disease, such as familial hypertrophic cardiomyopathy and arrythmogenic right ventricular cardiomyopathy type 2 (ARVD2). Others do not produce structural heart disease and so are difficult to detect. Most of these cardiomyopathies are due to mutations in plasmalemmal cardiac ion channels, mainly the $\mathrm{Na}^{+}$channel and several $\mathrm{K}^{+}$channels (Lehnart et al., 2007). These mutations promote arrhythmogenesis by altering the action potential (AP) duration, which therefore may enhance the propensity of arrhythmic activity via the development of early after depolarizations (EADs). However, the recent finding of mutations in the $\mathrm{Ca}^{2+}$ release channel (RyR2) associated with catecholaminergic polymorphic ventricular tachycardia 
(CPVT) and ARVD2 has opened a new view of arrhythmogenesis, evidencing that alterations in intracellular $\mathrm{Ca}^{2+}$ cycling can generate arrhythmia (Priori SG, 2001). CPVT is a familial arrhythmogenic disorder characterised by syncopal events and Sudden Cardiac Death occurring in children and young adults during physical stress or emotion in the absence of structural heart disease. In addition to the severe phenotype, CPVT exhibits a cumulative mortality of $30-50 \%$ by 35 years. To date, more than 145 RyR 2 mutations have been identified as causative of CPVT in affected individuals, which appear clustered in 3 "hot spots". Some of these mutations have been investigated in several in vitro systems (lipid bilayers, HEK293 cells, HL1-cardiomyocytes), suggesting that CPVT-linked RyR2 mutations produced an increase of the RyR2 activity, termed as RyR2 $\mathrm{Ca}^{2+}$ leakage, under beta-adrenergic stimulation (Lehnart et al., 2004). This abnormal SR $\mathrm{Ca}^{2+}$ release during diastole would activate the $\mathrm{Na}^{+}-\mathrm{Ca}^{2+}$ exchanger (NCX) to extrude $\mathrm{Ca}^{2+}$ out of the cell. Since NCX is electrogenic, a net inward current is generated for each $\mathrm{Ca}^{2+}$ ion extruded, which could develop delayed after depolarizations (DADs) and evoke triggered activity if they reach threshold. This abnormality may promote arrhythmogenesis in CPVT patients, where the increased RyR2 activity may generate DADs through the activation of NCX (Nakajima et $a l ., 1997)$. This mechanism is interestingly very similar to the one that has been suggested in $\mathrm{HF}$, where chronic hyperadrenergic state generates an inadequate diastolic $\mathrm{Ca}^{2+}$ release $\left(\mathrm{Ca}^{2+}\right.$ leak) and SR $\mathrm{Ca}^{2+}$ depletion, leading to a decreased myocardial contractility. Recently, Priori's laboratory has developed a knock-in mouse model carrying a highly penetrant R4496C mutation in the RyR2 (equivalent to the human R4497C mutation), identified in an Italian family with CPVT. Previous reports have shown that these mice developed bidirectional and polymorphic ventricular tachycardia under the injection of isoproterenol ( $\beta$-adrenergic agonist) and caffeine (Cerrone et al., 2005). Interestingly, the presence of DADs was detected after high pacing rates and under the application of isoproterenol, in isolated ventricular myocytes (Liu et al., 2006). Our laboratory has also performed experiments using this mouse model and, in addition to other findings, we observed abnormal cytosolic $\mathrm{Ca}^{2+}$ release and spontaneous triggering activity, in ventricular myocytes paced at high rates or treated with isoproterenol (Fernandez-Velasco M, et al 2009). In this chapter, we will review the latest knowledge on the role of intracellular $\mathrm{Ca}^{2+}$ on cardiac arrhythmia in acquired and inherited diseases, paying special attention to the molecular and cellular mechanisms of the disease.

\section{Involvement of RyR in cardiac arrhythmias}

The cardiac RyR is the major $\mathrm{Ca}^{2+}$ release channel in the ventricle and it is central in activating contraction by the mechanism of $\mathrm{Ca}^{2+}$-induced $\mathrm{Ca}^{2+}$ release during the excitation-contraction process. It is located in the membrane of the SR, mainly in the junctional SR, facing the L-type $\mathrm{Ca}^{2+}$ channels located in the membrane invaginations termed trasverse tubules. During cardiac excitation-contraction coupling (ECC), the membrane depolarization during the AP activates $\mathrm{Ca}^{2+}$ influx via sarcolemmal L-type $\mathrm{Ca}^{2+}$ channels, providing enough $\mathrm{Ca}^{2+}$ to activate the RyR (Fabiato, 1983; Bers, 2002). By this mechanism, the initial $\mathrm{Ca}^{2+}$ signal is greatly amplified, then providing enough $\mathrm{Ca}^{2+}$ for contraction. Relaxation occurs when calcium is removed from cytosol, mainly by NCX and SR $\mathrm{Ca}^{2+}$-ATPase (SERCA). The sarcolemmal $\mathrm{Ca}^{2+}$ ATPase, different from SERCA, can also extrude some $\mathrm{Ca}^{2+}$. However, its contribution appears to be minor (about $3 \%$ of total $\mathrm{Ca}^{2+}$ removal) and its physiological significance has yet to be determined. For equilibrium to occur, the amount of $\mathrm{Ca}^{2+}$ extruded through the NCX should be equivalent to the amount of $\mathrm{Ca}^{2+}$ entering the cell through DHPRs, and the amount of $\mathrm{Ca}^{2+}$ 
transported by SERCA should be equivalent to $\mathrm{Ca}^{2+}$ released by the SR. For each $\mathrm{Ca}^{2+}$ extruded, the NCX enters $3 \mathrm{Na}^{+}$, generating thus an inward current. In cases of $\mathrm{Ca}^{2+}$ overload, spontaneous SR $\mathrm{Ca}^{2+}$ release through RyRs produces $\mathrm{Ca}^{2+}$ waves, activating transient inward currents (Iti), (Berlin et al., 1989) which if they reach threshold may trigger an action potential (triggered activity). The NCX is centrally involved in this current (Venetucci et al., 2007). Triggered activity-derived arrhythmias are produced by after depolarizations that can occur early during the repolarization phase of the action potential (early after depolarization, EAD) or late, after completion of the repolarization phase (delayed after depolarization, DAD) (Figure 1). When either type of after depolarization is large enough to reach the threshold potential for activation of a regenerative inward current, a new AP is generated, which is named as triggered activity.

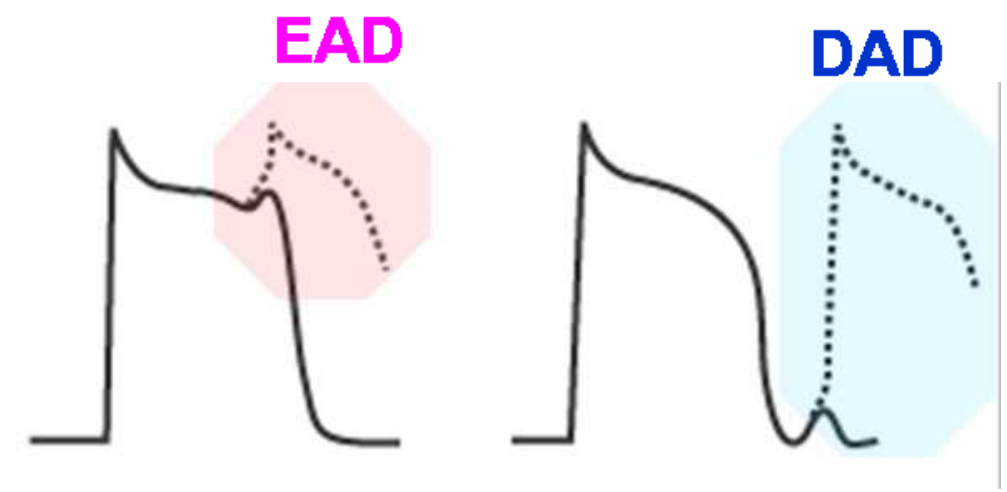

Fig. 1. Example of an early after depolarization (EAD) and delayed after depolarization (DAD) leading to triggered activity.

\section{Involvement of RyR in cardiac arrhythmias in the hypertrophied and failing heart}

Half of the deaths in heart failure patients are due to sudden death and cardiac hypertrophy has also an elevated risk of sudden death, which may arise as a consequence of ventricular arrhythmia. The ventricular cardiomyocytes of these hearts are prolonged, which favors the occurrence of early EADs. EADs are believed to be dependent on the L-type $\mathrm{Ca}^{2+}$ channel. DADs are common of $\mathrm{Ca}^{2+}$ overloaded cells, which is uncommon in heart failure. However, the RyR activity is altered, which may favor DADs. Several modifications that happen in the RyR of the failing hearts have been shown to promote diastolic $\mathrm{Ca}^{2+}$ leak and be arrhythmogenic. These modulations include phosphorylation (PKA and/or CaMKII), oxidation, decreased nitrosylation, lost of its accessory protein FKBP12.6 (calstabin 2) and unzipping. However, the RyR leakiness would not be enough to provoke arrhythmia, because it should be compensated by the reduction in SR Ca²+ load (Venetucci et al., 2008). Hyperphosphorylation of RyR by PKA was found in humans at end stage heart failure and different models of heart failure (Marx et al., 2000; Reiken et al., 2003) and related to sudden death (Marks, 2001), although controversed (Jiang et al., 2002). RyR phosphorylation increases activity of RyR, making RyR leaky and thus favoring arrhythmia. The RyR is also hyperphosphorylated at the CaMKII site (Ai et al., 2005) during heart failure, which may be 
involved in the propensity to arrhythmias. In this sense, CaMKII blockade repressed the spontaneous $\mathrm{Ca}^{2+}$ waves in heart failure cardiomyocytes (Curran et al.).

RyR phosphorylation in heart failure has been suggested to unbind the RyR from its regulatory protein, the FKBP12.6 (Marx et al., 2000). While the direct correlation with phosphorylation is a matter of debate (Maier et al., 2003; Blayney et al., 2010), the cardiac expression of FKBP12.6 is reduced in heart failure, causing diastolic $\mathrm{Ca}^{2+}$ leak that may result in higher propensity of DADs and consequent triggered arrhythmias (Shou et al., 1998; Yano et al., 2000; Reiken et al., 2001; Xin et al., 2002; Wehrens et al., 2004; Ai et al., 2005; Wehrens et al., 2005; Yano et al., 2005; Huang et al., 2006; Yano et al., 2006; Gomez et al., 2009). Supporting the role of FKBP12.6 in arrhythmia, stabilizing FKBP12.6 binding to RyR by FKBP12.6 overexpression prevents triggered arrhythmias in normal hearts, probably by reducing diastolic SR Ca ${ }^{2+}$ leakage (Gellen et al., 2008). Conversely, FKBP12.6 knockouts exhibited exercise induced ventricular arrhythmia (Wehrens et al., 2003).

Other alterations during heart failure may affect RyR function. In this sense, RyR oxidation in a canine model of sudden death are involved in arrythmogenic $\left[\mathrm{Ca}^{2+}\right]_{i}$ transients alternans (Belevych et al., 2009). Moreover, the increase in xantine oxidase activity also reduces the level of S-nytrosilation. The RyR hyponitrosylation has also been involved in the $\mathrm{Ca}^{2+}$ leak from SR in experimental heart failure (Gonzalez et al., 2010). This alteration might contribute to the arrhythmogenesis in heart failure. In this sense, it has been shown that NOS1-/- mice show RyR hyponitrosylation with consequent SR $\mathrm{Ca}^{2+}$ leak and an arrhythmic phenotype, without altering the FKBP12.6 stoichiometry (Gonzalez et al., 2007). Consistent with these findings, NOS1 overexpression protected the mice in a model of heart failure by preserving $\mathrm{Ca}^{2+} \mathrm{Cycling}$ (Loyer et al., 2008). However, others have found that RyR is hypernitrosilated in a model of muscular dystrophy, where arrhythmias are frequent, suggesting that hypernytrosilated RyR is leaky. It should be noted that in this model the binding to FKBP12.6 was also decreased (Fauconnier et al., 2010), which may account for the RyR leakiness.

The N and central domains of the RyR interact with each other in a process called "zipping", which stabilizes the channel in its closed state (Ikemoto \& Yamamoto, 2002). In heart failure, the RyR is unzipped favoring its phosphorylation and unbinding to FKBP12.6 (Oda et al., 2005).

Besides these direct alterations of the RyR, this channel may be "sensitized" in some conditions by an increase in the local $\left[\mathrm{Ca}^{2+}\right]$ around it, from either side of the SR membrane. In this sense, the increase in the IP3R expression in the junctional SR during heart failure might, under certain circumstances, locally increase the $\left[\mathrm{Ca}^{2+}\right]_{\mathrm{i}}$ in the neighboring RyRs and facilitate $\mathrm{Ca}^{2+}$ waves propagation (Harzheim et al., 2009). Increasing the $\left[\mathrm{Ca}^{2+}\right]_{\mathrm{i}}$ in the luminal side, as by an increase in SERCA activity, might also sensitize the RyR and participate in $\mathrm{Ca}^{2+}$ waves formation (Keller et al., 2007) although SERCA activity is thought to be depressed in heart failure.

\section{Involvement of RyR in inherited cardiac arrhythmias}

\subsection{Catecholaminergic polymorphic ventricular tachycardia}

CPVT is a rare arrhythmogenic disease characterized by exercise or stress induced ventricular tachyarrhythmia, syncope, or sudden death that appear in individuals with 
structural normal hearts (Leenhardt et al., 1995; Coumel, 1997; Priori et al., 2002). Because the electrocardiogram (ECG) of CPVT patients is unremarkable under basal conditions, the diagnosis is established in symptoms and the detection of stress-induced arrhythmias during exercise test or Holter recording. Although some CPVT patients develop polymorphic ventricular tachycardia (VT), the bidirectional VT is considered the diagnostic marker of CPVT (Priori et al., 2002). Interestingly, bidirectional VT occurs during digitalis intoxication, where the $\mathrm{Na}^{+} / \mathrm{K}^{+}$ATPase pump is inhibited, increasing the intracellular $\mathrm{Na}^{+}$concentration that in turn, by $\mathrm{NCX}$ induces an intracellular $\mathrm{Ca}^{2+}$ overload, triggering arrhythmogenic DADs (Rosen \& Danilo, 1980). Thus, it was reasonable to postulate that bidirectional VT in CPVT patients can be due to changes in the intracellular calcium handling. Indeed, several reports have associated CPVT with mutations in genes encoding key-proteins involved in the control of intracellular calcium handling, such as RyR2 and calsequestrin (CASQ2), causative of CPVT1 and CPVT2, respectively (Lahat et al., 2001a; Priori et al., 2002).

\subsection{RyR2 mutations in CPVT}

The gene encoding RyR2 (chromosome 1q42.1-43) consists of 105 exons, which encodes 4967 amino acids $(\sim 560 \mathrm{kDa})$ and it is one of the largest and most intricate in the human genome. The RyR2 is a homotetramer with hydrophobic segments of the four identical subunits forming a central $\mathrm{Ca}^{2+}$ pore (Wagenknecht, 1989). Currently more than $145 \mathrm{RyR} 2$ mutations have been reported as causative of CPVT, and they continue growing since the first mutations was reported a decade ago (Priori SG, 2001) - an updated database is shown in the 'Gene connection for the heart' website (http://www.fsm.it/cardmoc/). Some of these RyR2 mutations have been identified in patient groups screened for Long QT syndrome (Tester DJ, 2005), and ARVD2 (Tiso et al., 2001). CPVT-related arrhythmias are by far reproduced during an exercise stress test, by isoproterenol infusion, or by other forms of adrenergic stimulation (Sumitomo et al., 2003; Vyas et al., 2006). A genetic screening of RyR2 is necessary to verify the disease in patients suspicious of CPVT1, although this strategy is time consuming and expensive. However, screening for RyR2 mutations could be simplified due to the circumstance that CPVT mutations used to cluster in certain exons, and a tiered scan of these exons can be used to lower the cost (Medeiros-Domingo A, 2009). RyR2 mutations linked to CPVT are clustered into 3 discrete protein regions or "hot spots": Nterminus (32\% ), central domain (30\% ) and C-terminus (38\%) (Yano et al., 2006; George CH, 2007). Similar mutation clustering is observed in the $R Y R 1$ gene, which encodes the skeletal muscle RyR1 and is linked to malignant hyperthermia and central core disease (Dirksen, 2002). The N-terminus (also called domain I: amino acids 77-466) is a domain particularly susceptible to conformational change. It contains the cytoplasmic loop, which it is postulated that interacts with the central domain (zipping) stabilizing RyR2 activity during diastole (Yamamoto T, 2000). The central domain (domain II: amino acids 2246-2534) contains an FKBP12.6 binding domain (1636-1937) and it is supposed to interact with the Nterminus domain (zipping-unzipping). The C-terminus domain (domain III: amino acids 3778-4201 and domain IV: amino acids 4497 to 4959) contains the transmembrane regions of the $\mathrm{Ca}^{2+}$ channel and an hydrophobic region which it is postulated to transduce cytoplasmic events to regulate the $\mathrm{Ca}^{2+}$ pore forming domain (George $\left.\mathrm{CH} ., 2006\right)$. Only a small number of mutations are located in regions of RyR2 outside these portions. By contrast to other 
channelopathies, most of the RyR2 mutations described in CPVT are single nucleotide replacements ("point mutations") leading to an amino acid substitution.

\subsection{Functional alterations of CPVT related mutations in the RyR}

Although the phenotypic manifestation of CPVT is usually the stress-induced development of bidirectional or polymorphic ventricular tachycardia, patient symptoms are heterogeneous, presenting in some cases high variability among affected subjects within the same family (d'Amati \& King, 2005). However in other cases, patients with point mutations located in the same RyR2 cluster present similar CPVT symptoms, probably because they affect RyR2 function in a common way. To improve the current knowledge of RyR2 complexity and to provide an adequate treatment to CPVT patients, it is necessary to study the molecular mechanisms of all sudden cardiac death (SCD)-linked mutations screened. A number of studies on them have been undertaken. Most of them have been analyzed in heterologous systems, but some transgenic mice have been constructed, allowing the exploration of the cardiac function.

CPVT-linked mutations have been expressed in various heterologous systems (lipid bilayer, HEK293 cells, HL1-cardiomyocytes). Specifically, HEK293 cells (human embryonic kidney cell line) have been widely used as an expression system. This cell line presents some weak points such as it lacks ECC proteins and the contractile machinery that characterizes heart cells. However, it presents several advantages: 1) it is easy to transfect using conventional methods and, 2) as it does not express native RyR, they cannot interfere with expressed constructs.

Some human N-terminus mutations (R176Q/T2504M and L433P), central domain mutations (S2246L and R2474S), and C-terminus mutations (N4104K, Q4201R, R4496C, I4867M and N4895D) have been explored using HEK293 cells. These RyR2 mutations showed an increased frequency of spontaneous $\mathrm{Ca}^{2+}$ oscillations and a reduced $\mathrm{Ca}^{2+}$ store content, thus displaying gain-of-function (Jiang et al., 2004; Jiang D, 2005). In addition, most mutated RyR2 incorporated into lipid bilayers displayed an increased sensitivity to luminal $\mathrm{Ca}^{2+}$, although the two N-terminus mutants were 10 -fold less sensitive than the others (Jiang D, 2005). However, some RyR2 mutants displayed an increased sensitivity to cytosolic $\mathrm{Ca}^{2+}$ and caffeine. This is the case for S2246L, N4104K and R4497C mutations expressed in HEK293 cells or HL-1 cells, where it was also shown a gain-of-function RyR2 activity, while there was no change in SR Ca ${ }^{2+}$ load (George CH., 2006). In some cases, differences in RyR2 mutants' response to agonists are closely dependent on the mutational locus. This may be the case of a report from Thomas and coworkers, who have observed marked differences in caffeine-dependent $\mathrm{Ca}^{2+}$ release in N-terminal and central domain ARVD2-linked RyR2 mutations (L433P, N2386I and R176Q/T2504M) (Thomas et al., 2004; George CH \& .2005). Interestingly, one of these 3 mutations (L433P) was not associated with gain-of-function, but rather with loss-of-function (George $\mathrm{CH} \&$. 2005).

It is of note that the characterization of RyR2 mutations according to the mutational locus may be of large interest because this permits to design a model which integrates domainspecific arrhythmogenic mechanisms. The result model could extrapolate how new mutations may affect RyR2 function, allowing for a common therapy that restores channel activity. Table 1 shows a classification of SCD-linked mutations characterized so far. 


\begin{tabular}{|c|c|c|c|c|c|}
\hline $\begin{array}{l}\text { Location in } \\
\text { RyR2 }\end{array}$ & Mutation & Disease & Characterization & System & $\begin{array}{l}\text { RyR2 } \\
\text { defect }\end{array}$ \\
\hline N-Terminal & R176Q & ARVD / SUO & \begin{tabular}{|l|} 
Enhanced SOICR increased \\
sensitivity to luminal Ca ${ }^{2+}$ (Jiang \\
D, 2005); R176Q/T2504M \\
increase caffeine-dependent \\
sensibility to cytosolic Ca2+ \\
(Thomas, 2005); myocytes elicited \\
oscillatory Ca ${ }^{2+}$ signals under $\beta-$ \\
adrenergic stimulation. \\
(Kannankeril et al., 2006)
\end{tabular} & $\begin{array}{l}\text { HEK293 } \\
\text { Lipid bilayers } \\
\text { Knock-in } \\
\text { mice }\end{array}$ & $\begin{array}{l}\text { Gain-of- } \\
\text { function }\end{array}$ \\
\hline N-Terminal & E189D & CPVT & $\begin{array}{l}\text { Increases the propensity of SOICR } \\
\text { and enhance caffeine sensitivity. } \\
\text { (Jiang D, 2010) }\end{array}$ & HEK293 & $\begin{array}{l}\text { Gain-of- } \\
\text { function }\end{array}$ \\
\hline N-Terminal & G230C & CPVT & $\begin{array}{l}\text { Increased sensibility to cytosolic } \\
\mathrm{Ca}^{2+} \text {, decreased FKBP-12.6 } \\
\text { binding (Meli, 2011) }\end{array}$ & \begin{tabular}{|l|} 
HEK293 \\
Lipid bilayers
\end{tabular} & $\begin{array}{l}\text { Gain-of- } \\
\text { function }\end{array}$ \\
\hline N-Terminal & L433P & ARVD & $\begin{array}{l}\text { Enhanced SOICR, increased } \\
\text { sensitivity to luminal } \mathrm{Ca}^{2+} \text { (Jiang } \\
\mathrm{D}, 2005) \\
\text { Decrease caffeine-dependent, } \\
\text { sensibility to cytosolic Ca }{ }^{2+} \\
\text { (Thomas, 2005), desensitized } \\
\text { response to caffeine (Thomas et } \\
\text { al., 2004) }\end{array}$ & $\begin{array}{l}\text { HEK293 } \\
\text { Lipid bilayers } \\
\text { HEK293 }\end{array}$ & $\begin{array}{l}\text { Gain-of- } \\
\text { function } \\
\\
\text { Loss-of- } \\
\text { function }\end{array}$ \\
\hline $\begin{array}{l}\text { Cytoplasmic } \\
\text { loop }\end{array}$ & G1885E & ARVC & $\begin{array}{l}\text { Enhanced SOICR, reduced RyR2 } \\
\text { activity in G1885E/G1886S } \\
\text { double mutant. (Koop, 2008) }\end{array}$ & HEK293 & $\begin{array}{l}\text { Gain-of- } \\
\text { function }\end{array}$ \\
\hline $\begin{array}{l}\text { Cytoplasmic } \\
\text { loop }\end{array}$ & G1886S & ARVC & $\begin{array}{l}\text { Enhanced SOICR, reduced RyR2 } \\
\text { activity in G1885E/G1886S } \\
\text { double mutant. (Koop, 2008) }\end{array}$ & HEK293 & $\begin{array}{l}\text { Gain-of- } \\
\text { function }\end{array}$ \\
\hline $\begin{array}{l}\text { Cytoplasmic } \\
\text { loop }\end{array}$ & S2246L & CPVT/IVF & $\begin{array}{l}\text { PKA-dependent increased RyR2 } \\
\text { activity (Wehrens et al., 2003); } \\
\text { PKA and caffeine-dependent } \\
\text { increased RyR2 activity (George } \\
\text { et al., 2003);abnormal domain } \\
\text { interaction (George CH., } \\
\text { 2006); enhanced SOICR, increased } \\
\text { sensitivity to luminal Ca2+ (Jiang } \\
\text { et al., 2004) }\end{array}$ & $\begin{array}{l}\text { HEK293 } \\
\text { Lipid bilayers } \\
\text { CHO } \\
\text { HL-1 }\end{array}$ & $\begin{array}{l}\text { Gain-of- } \\
\text { function }\end{array}$ \\
\hline $\begin{array}{l}\text { Cytoplasmic } \\
\text { loop }\end{array}$ & R2267H & CPVT & $\begin{array}{l}\text { PKA-dependent increased } \\
\text { sensitivity to cytosolic } \mathrm{Ca}^{2+} \\
\text { (Tester, 2007) }\end{array}$ & \begin{tabular}{|l|} 
HEK293 \\
Lipid bilayers
\end{tabular} & $\begin{array}{l}\text { Gain-of- } \\
\text { function }\end{array}$ \\
\hline $\begin{array}{l}\text { FKBP binding } \\
\text { dom. }\end{array}$ & P2328S & CPVT & $\begin{array}{l}\text { Decreased FKBP-12.6 binding, } \\
\text { PKA-dependent increased RyR2 } \\
\text { activity (Lehnart et al., 2004) }\end{array}$ & \begin{tabular}{|l|} 
HEK293 \\
Lipid bilayers
\end{tabular} & $\begin{array}{l}\text { Gain-of- } \\
\text { function }\end{array}$ \\
\hline $\begin{array}{l}\text { FKBP binding } \\
\text { dom. }\end{array}$ & N2386I & ARVD & $\begin{array}{l}\text { Increase caffeine-dependent, } \\
\text { sensibility to low cytosolic Ca2+ } \\
\text { (Thomas, 2005) }\end{array}$ & HEK293 & $\begin{array}{l}\text { Gain-of- } \\
\text { function }\end{array}$ \\
\hline
\end{tabular}




\begin{tabular}{|c|c|c|c|c|c|}
\hline $\begin{array}{l}\text { Location in } \\
\text { RyR2 }\end{array}$ & Mutation & Disease & Characterization & System & $\begin{array}{l}\text { RyR2 } \\
\text { defect }\end{array}$ \\
\hline $\begin{array}{l}\text { FKBP binding } \\
\text { dom }\end{array}$ & R2474S & CPVT & $\begin{array}{l}\text { Enhanced SOICR, increased } \\
\text { sensitivity to luminal Ca }{ }^{2+}(\mathrm{Jiang} \\
\mathrm{D}, 2004) ; \text { (Wehrens } \text { et al., 2003); } \\
\text { abnormal zipping-unzipping } \\
\text { interaction, increase caffeine- } \\
\text { dependent, sensibility to } \\
\text { cytosolic } \mathrm{Ca}^{2+}(\text { Yang, 2006); } \\
\text { increased frequency of } \\
\text { spontaneous Ca }{ }^{2+} \text { transients and } \\
\text { increased sensitivity to luminal } \\
\mathrm{Ca}^{2+} \text { mediated by defective } \\
\text { interdomain interaction. } \\
\text { (Uchinoumi } \text { et al., 1998) }\end{array}$ & $\begin{array}{l}\text { HEK293 } \\
\text { Lipid bilayers } \\
\text { Permeabilize } \\
\text { d myocytes } \\
\text { from rats } \\
\text { Knock-in } \\
\text { mice }\end{array}$ & $\begin{array}{l}\text { Gain-of- } \\
\text { function }\end{array}$ \\
\hline $\begin{array}{l}\text { FKBP binding } \\
\text { dom. }\end{array}$ & T2504M & ARVD & $\begin{array}{l}\text { R176Q/T2504M increase } \\
\text { caffeine-dependent sensibility to } \\
\text { cytosolic Ca }{ }^{2+} \text { (Thomas, 2005); } \\
\text { R176Q/T2504M enhance SOICR } \\
\text { and increase sensitivity to } \\
\text { luminal } \mathrm{Ca}^{2+} \text { (Jiang D, 2005) }\end{array}$ & \begin{tabular}{|l} 
HEK293 \\
Lipid bilayers
\end{tabular} & $\begin{array}{l}\text { Gain-of- } \\
\text { function }\end{array}$ \\
\hline TM Domain & N4104K & CPVT & $\begin{array}{l}\text { PKA and caffeine-dependent } \\
\text { increased RyR2 activity (George et } \\
\text { al., 2003); abnormal I domain } \\
\text { interaction (George CH., 2006); } \\
\text { enhanced SOICR (Jiang D, 2005); } \\
\text { increased sensitivity to luminal } \\
\text { Ca2+ (Jiang D, 2004) }\end{array}$ & $\begin{array}{l}\text { HEK293 } \\
\text { Lipid bilayers } \\
\text { CHO } \\
\text { HL-1 }\end{array}$ & $\begin{array}{l}\text { Gain-of- } \\
\text { function }\end{array}$ \\
\hline TM Domain & Q4201R & CPVT & $\begin{array}{l}\text { Ehanced SOICR, increased } \\
\text { sensitivity to luminal } \mathrm{Ca}^{2+}(\mathrm{Jiang} \\
\mathrm{D}, 2005) \text {; decreased FKBP-12.6 } \\
\text { binding, PKA-dependent } \\
\text { increased RyR2 activity (Lehnart } \\
\text { et al., 2004) }\end{array}$ & $\begin{array}{l}\text { HEK293 } \\
\text { Lipid bilayers }\end{array}$ & $\begin{array}{l}\text { Gain-of- } \\
\text { function }\end{array}$ \\
\hline TM Domain & R4497C & CPVT & $\begin{array}{l}\text { PKA-dependent increased RyR2 } \\
\text { activity (Wehrens et al., 2003); } \\
\text { PKA and caffeine-dependent } \\
\text { increased RyR2 activity (George } \\
\text { et al., 2003); abnormal I domain } \\
\text { interaction (Uchinoumi } \text { et al., } \\
\text { 1998); enhanced SOICR (Jiang D, } \\
\text { 2005); increased sensitivity to } \\
\text { luminal Ca2+ (Jiang } \text { et al., 2004); } \\
\text { increased sensitivity to low } \\
\text { cytosolic Ca }{ }^{2+} \text {, caffeine- } \\
\text { dependent increased RyR2 (Jiang } \\
\text { et al., 2002); Increased sensitivity } \\
\text { to cytosolic Ca²+, triggering } \\
\text { activity in ventricular myocytes } \\
\text { in presence of high pacing rate } \\
\text { and isoproterenol. (Fernandez- } \\
\text { Velasco } \text { et al., 2009) }\end{array}$ & $\begin{array}{l}\text { HEK-293 } \\
\text { Lipid bilayer } \\
\text { CHO } \\
\text { HL-1 } \\
\text { Knock-in ce }\end{array}$ & $\begin{array}{l}\text { Gain-of- } \\
\text { function }\end{array}$ \\
\hline
\end{tabular}




\begin{tabular}{|c|c|c|c|c|c|}
\hline $\begin{array}{l}\text { Location in } \\
\text { RyR2 }\end{array}$ & Mutation & Disease & Characterization & System & $\begin{array}{l}\text { RyR2 } \\
\text { defect }\end{array}$ \\
\hline TM Domain & V4653F & CPVT & $\begin{array}{l}\text { Decreased FKBP-12.6 binding, } \\
\text { PKA-dependent increased RyR2 } \\
\text { activity (Lehnart et al., 2004); } \\
\text { Increased sensitivity to cytosolic } \\
\mathrm{Ca}^{2+} \text { (Tester, 2007) }\end{array}$ & $\begin{array}{l}\text { HEK293 } \\
\text { Lipid bilayers }\end{array}$ & $\begin{array}{l}\text { gain-of- } \\
\text { function }\end{array}$ \\
\hline TM Domain & A4860G & IVF & $\begin{array}{l}\text { Reduced sensitivity to luminal } \\
\mathrm{Ca}^{2+} \text {, reduced SOICR activity } \\
(\text { (Jiang D, 2007) }\end{array}$ & $\begin{array}{l}\text { HEK293 } \\
\text { Lipid bilayers }\end{array}$ & $\begin{array}{l}\text { Loss-of- } \\
\text { function }\end{array}$ \\
\hline C-term & $\mathrm{I} 4867 \mathrm{M}$ & CPVT & $\begin{array}{l}\text { Enhanced SOICR, increased } \\
\text { sensitivity to luminal } \mathrm{Ca}^{2+} \text { (Jiang } \\
\mathrm{D}, 2005)\end{array}$ & $\begin{array}{l}\text { HEK293 } \\
\text { Lipid bilayers }\end{array}$ & $\begin{array}{l}\text { Gain-of- } \\
\text { function }\end{array}$ \\
\hline C-term & N4895D & CPVT & $\begin{array}{l}\text { Enhanced SOICR, increased } \\
\text { sensitivity to luminal } \mathrm{Ca}^{2+} \text { (Jiang } \\
\text { D, 2004) }\end{array}$ & $\begin{array}{l}\text { HEK293 } \\
\text { Lipid bilayers }\end{array}$ & $\begin{array}{l}\text { Gain-of- } \\
\text { function }\end{array}$ \\
\hline
\end{tabular}

Table 1. RyR2 mutations linked to SCD disease characterized so far. Amino acid mutations are listed in order according to the mutational locus. CPVT=Catecholaminergic Polymorphic Ventricular Tachycardia; ARVD=Arrhythmogenic Right Ventricular Dysplasia; IVF = Idiopathic Ventricular Fibrillation induced by emotion or exercise. TM = Transmembrane domain; $\mathrm{SUO}=$ syncope of unknown origin;; SOICR = Store-operated induced- Ca2+ release; HEK293 = Human embrionic kidney cell line; $\mathrm{CHO}=$ Chinese hamster ovary cell line; HL-1 = cardiac myocyte cell line.

Because animal's models can contribute to the better understanding of the molecular mechanisms involved in the arrhythmogenic disease, transgenic mice models that harbor some of the most important RyR2 mutations observed in CPVT patients were developed (Uchinoumi et al., ; Cerrone et al., 2005; Kannankeril et al., 2006).

These animals mimic several of the abnormal electrical events observed in CPVT subjects. Indeed, delayed after depolarization (DADs) and triggered activity have been detected in knock-in models of CPVT (Liu et al., 2006). It has been proven by different authors that cardiac myocytes isolated from CPVT models show abnormal diastolic $\mathrm{Ca}^{2+}$ release $\left(\mathrm{Ca}^{2+}\right.$ leak) as $\mathrm{Ca}^{2+}$ sparks and/or $\mathrm{Ca}^{2+}$ waves, which may conduce to arrhythmia by DADs (Uchinoumi et al., ; Kannankeril et al., 2006; Fernandez-Velasco et al., 2009).

One mice model that harbor RyR2 (R2474S) mutation leading to CPVT upon exercise and $\beta$ adrenergic stimulation was developed by Lehnart et al., (Lehnart et al., 2008). Cardiomyocytes isolated from R2474S mice exhibited abnormal calcium diastolic leak, calcium waves, APs and inward currents upon isoproterenol treatment. Tonic-clonic seizures were identified in these mice, consistent with the neurological dysfunction including epilepic seizures detected in CPVT patients (Leenhardt et al., 1995; Postma et al., 2005; Lehnart et al., 2008).

Another mechanism by which mutation can alter the calcium handling in CPVT is the disruption of protein-protein interaction. In this context, Wehrens et al., established a direct link between FKBP12.6 and CPVT process (Wehrens et al., 2004). FKBP12.6 (calstabin 2) is an accessory subunit that maintains the RyR2 closed, avoiding calcium leak during diastole. Wehrens et al., proposed that CPVT mutations induce the dissociation of FKBP12.6 from RyR2 upon $\beta$-adrenergic stimulation. Therefore, this effect induces a deregulation of the 
RyR2 gating, increasing the calcium diastolic release and promoting cardiac arrhythmias by delayed after depolarizations (Marx SO, 2000). Indeed, these authors showed that the presence of different CPVT mutations decreases the affinity of FKBP12.6 binding to RyR, leading to calcium leak (Marx SO, 2000; Wehrens et al., 2003; Lehnart et al., 2008)\}. However, these findings have not been confirmed by others groups (Tiso et al., 2002; George et al., 2003; Liu et al., 2006; Xiao et al., 2007; Guo et al., 2010).

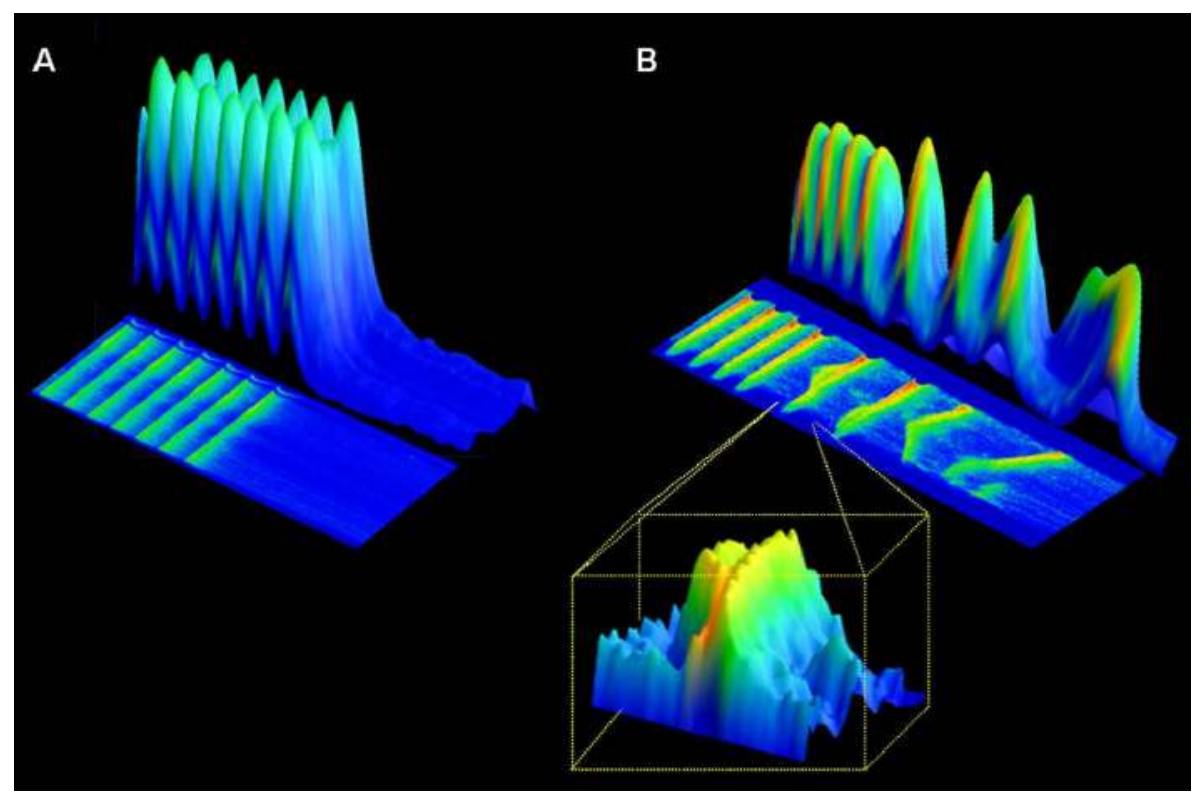

Fig. 2. Triggered activity observed in RyR2R4496C myocytes. 3D line-scan images of ventricular myocytes isolated from (A) a wild type mouse and (B) RyR ${ }^{\mathrm{R} 4496 \mathrm{C}}$ mouse during electrical stimulation $(4 \mathrm{~Hz})$. RyR ${ }^{\mathrm{R} 496 \mathrm{C}}$ cell shows $\mathrm{Ca}^{2+}$-waves that induce consistent with DADs. Finally Matsusaki's group has described altered interdomain RyR2 interactions in CPVT (Ikemoto \& Yamamoto, 2000; Tateishi et al., 2009). They proposed that under physiological conditions, $\mathrm{N}$ and central terminal domains of RyR2 interact, maintaining the channel closed. CPVT-linked mutations in the $\mathrm{N}$ or central domain, causing a disruption of the interaction (domain unzipping), rendering the channel more sensitive to changes in luminal or cytosolic calcium. So, it is reasonable to hypothesize that mutations in these regions of RyR2 could affect the physiological conformational states, resulting in channel dysfunction, as occurs in CPVT (Lobo \& Van Petegem, 2009; Tung et al., 2010).

On the other hand, our group using a knock-in mice model that express R4496C mutation in the cardiac RyR2 (the equivalent mutation found in CPVT patients, R4497C) demonstrated an enhanced of $\mathrm{Ca}^{2+}$ sensitivity of the mutant RyR2 (Fernandez-Velasco et al., 2009). This mice model mimics extraordinarily the clinical manifestations of patients presenting the RyR2R4497C mutation, including the bidirectional VT. RyR2R4496C cardiomyocytes exposed to adrenaline and caffeine developed DADs, suggesting that triggered arrhythmias are elicited by adrenergic activation (Nakajima et al., 1997; Liu et al., 2006). We demonstrated 
that untreated RyR2R4496C myocytes have increased spontaneous $\mathrm{Ca}^{2+}$ release in diastole during electrical pacing, due to the enhanced $\mathrm{Ca}^{2+}$ sensitivity of mutant RyR2; this abnormality is further augmented by exposure to isoproterenol and increasing pacing rates (Figure 2).

\subsection{Mutations in calsequestrin 2 linked to CPVT}

As previously mentioned, alterations in the control of $\mathrm{Ca}^{2+}$ release by changes in luminal calcium can induce serious disruptions in the $\mathrm{Ca}^{2+}$ cycling. This is what happens in the recessive form of CPVT associated with mutations in calsequestrin (CASQ2) (Eldar et al., 2003). CASQ2 is a polymer with a low-affinity and high capacity of calcium binding located in the luminal side of SR (Beard et al., 2004; Gyorke \& Terentyev, 2008). Although it is documented that CASQ2 interacts with RyR2 via triadin and junctin, and acts as luminal calcium sensor by inhibiting RyR2 function at low luminal calcium concentration (Gyorke et al., 2004; Terentyev et al., 2007), the exact mechanism by which this protein exerts their function is not completely understood.

To date, 12 CASQ2-mutations and 3 non synonymous polymorphisms have been detected in CPVT subjects (http://www.fsm.it/cardmoc/). Although some of these mutations affect the protein synthesis, reducing significantly the CASQ2 expression in the heart, others induce a defective protein expression and alter the ability of SR calcium buffering (Postma et al., 2002; Terentyev et al., 2003; di Barletta et al., 2006; Knollmann et al., 2006; Terentyev et al., 2006). Related to this, different authors have shown in murine cardiomyocytes and in heterologous systems, that mutants of CASQ2 including CASQ2 (L167H), CASQ2 (G112+5X), CASQ2 (R33Q), CASQ2-/- and CASQ2 (D307H) induce a deregulation of SR $\mathrm{Ca}^{2+}$ release, leading to arrhythmogenic DADs (Lahat et al., 2001a; Lahat et al., 2001b; Terentyev et al., 2003; di Barletta et al., 2006; Knollmann et al., 2006; Terentyev et al., 2006; Dirksen et al., 2007). These observations are consistent with the ECG pattern observed in CPVT patients (Napolitano \& Priori, 2007).

Missense and nonsense CASQ2 mutations have been reported. Regarding missense mutations, CASQ2 (D307H), CASQ2 (R33Q) and CASQ2 (L67H) have been found in CPVT subjects (Terentyev et al., 2006; Kim et al., 2007; Qin et al., 2008; Terentyev et al., 2008). These mutations alter the CASQ2 interaction with RyR2, compromising its ability to store $\mathrm{Ca}^{2+}$ in the SR. So far, it has been reported that there are four nonsense mutations that cause the protein to be reduced or deleted (di Barletta et al., 2006). In vivo, CASQ2-/- mice exhibit CPVT with a bidirectional QRS pattern, the classic ECG feature observed in their human disease (Knollmann et al., 2006).

Cellular arrhythmias were detected in cardiomyocytes expressing CASQ2 mutants under $\beta$ adrenergic stimulation (Terentyev et al., 2003; di Barletta et al., 2006; Dirksen et al., 2007). These results are consistent with the arrhythmogenic storm elicited by the emotional or physical stress in CPVT patients.

Because there is a correlation between the spontaneous $\mathrm{Ca}^{2+}$ release and the DADs, the question is why the spontaneous calcium release occurs. Different approaches address that mutations in CASQ2 compromise the two principal functions described for this protein: as a SR Ca ${ }^{2+}$ storage site and as modulator of RyR2 activity (Kubalova et al., 2005; Terentyev et al., 2006; Terentyev et al., 2008; Knollmann, 2009). Both mechanisms elicited an abnormal 
control of RyR2 by luminal $\mathrm{Ca}^{2+}$ required to effective termination of $\mathrm{SR} \mathrm{Ca}^{2+}$ release, promoting the spontaneous $\mathrm{Ca}^{2+}$ release during diastole. Studies using transgenic CPVT mice models with CASQ2 mutations confirm that the underlying mechanism of ventricular arrhythmias are DADs caused by spontaneous $\mathrm{Ca}^{2+}$ release under adrenergic stress (Mohamed et al., 2007). However, it is important to note that compensatory changes observed in the CASQ2 transgenic mice can alter the junctin and/or triadin function and may affect the manifestation of CPVT under chronic procedures. (Knollmann et al., 2006; Song et al., 2007).

\section{Supraventricular arrhythmias in CPVT}

CPVT patients often develop supraventricular arrhythmias as resting bradycardia and HisPurkinje block (Sumitomo et al., 2003; Cerrone M, 2007; Sumitomo et al., 2007; Kazemian P, 2011; Sy RW, 2011). Supraventricular arrhythmias (SVAs) are an important issue to underline during following-up patients with CPVT. Although the risk for SCD in CPVT patients is expected to be associated with ventricular arrhythmias, supraventricular abnormalities as sinus node dysfunction, atrioventricular block and supraventricular tachyarrhythmias result in significant increase of morbidity. Moreover, the frequent association of supraventricular arrhythmias in CPVT patients, which has been reported to precede or coexist with ventricular tachycardia, suggests that SVAs may be an important risk factor for SCD in this patient population (Sumitomo et al., 2007; Sy RW, 2011). These SVAs in single point mutations of RyR2 are usually bradycardia, atrial tachycardia, atrial fibrillation and atrioventricular reentry (Sumitomo et al., 2003; Sumitomo et al., 2007; Kazemian P, 2011; Sy RW, 2011). Additionally, Bhuiyan and coworkers found CPVT patients from 2 unlinked families with a deletion of 35 peptides in RyR2 exon-3, who presented also SVAs (sinus bradycardia, sinus block or arrest, atrioventricular block, atrial fibrillation and atrial standstill). Interestingly, these patients also presented left ventricular dysfunction and dilatation, which are rare in CPVT patients.

Additionally, prevention of SVAs is also important in CPVT disease due to potential complications with implantable cardioverter- defibrillators (ICD) therapy. In CPVT, betablockers are recommended, together with exercise restraint. Despite beta-blocker therapy, ICD are implanted in patients with previous cardiac arrest, or with recurrent syncope or documented ventricular tachycardia. However, SVAs are not benign arrhythmias in patients with CPVT; they potentially can trigger fast ventricular tachycardias and inappropriate ICD discharges that may lead to fatal ventricular arrhythmias (Pizzale et al., 2008). In the study by Sy and co-workers (Sy RW, 2011), one patient died of refractory ventricular tachycardia/ventricular fibrillation caused by inappropriate ICD shocks of rapidly conducting atrial fibrillation.

The cellular mechanism of sinus bradycardia in CPVT is still unexplored. One possibility is that the function of one or several ion channels that participate in the $\mathrm{Ca}^{2+}$ clock mechanism is altered (i.e. NCX, L-type $\mathrm{Ca}^{2+}$ channel, etc.) and this abnormality may correspond to a $\mathrm{Ca}^{2+}$ and voltage clock uncoupling. It has been reported that the CPVT-linked mutation R4496C presents an increased "SR $\mathrm{Ca}^{2+}$ leak" in ventricular myocytes isolated from a transgenic mice (Fernandez-Velasco et al., 2009). A combined genetic and functional approach would be highly required to explore the involvement of RyR mutations on bradycardia and sino-atrial node dysfunction in CPVT disease. 


\section{Purkinje conduction system}

The His-Purkinje system is responsible of the propagation for the action potential to the ventricles. The electrical properties of Purkinje cells are different from those of nodal cells, because they displayed low pacemaker activity and even slower conduction rate. However, Purkinje cells exhibit long action potential duration (APD) and therefore they are prone to EAD and DAD formation (Makarand Deo, 2010). This long APD provides sufficient time for L-type calcium channel reactivation, leading to EAD or DAD formation, which can lead to ectopic beats. Although EADs formation in Purkinje fibers has been quite explored (Fedida $\mathrm{D}, 2006)$, little is known concerning the development of DADs in these cardiac conducting fibers (GR., 1980; Gough WB, 1989). It has been recently described that DADs are associated to the development of CPVT disease (Liu et al., 2006; Fernandez-Velasco et al., 2009), but the mechanism of how DADs induce bidirectional VT is unknown. To fulfill this question, Cerrone and co-workers performed whole-heart optical mapping in heart isolated from knock-in mice carrying the R4496C mutation, and they found that bidirectional VT was caused by two foci in the distal His-Purkinje system, one in the right ventricle and the other in the left ventricle, activating the ventricles alternatively (Cerrone M, 2007). Polymorphic VT was initially multifocal but eventually became reentrant and degenerated into ventricular fibrillation. Moreover, chemical ablation of the right ventricular His-Purkinje system with Lugol solution converted bidirectional VT to monomorphic VT in mice. The same group further demonstrated in an additional report that Purkinje cells are more sensitive to the R4496C RyR2 mutation than ventricular myocytes, which strongly supports the idea that Purkinje cells are responsible of the arrhythmia in CPVT (Herron TJ, 2010). The latter result was further explored by other work, which has also tested that Flecainide reduce spontaneous $\mathrm{Ca}^{2+}$ release in Purkinje cells (Kang G, 2010).

\subsection{Treatment of CPVT}

Although $\beta$-adrenergic blockers is the most common treatment chosen for CPVT patients, they are incompletely effective with up to $30 \%$ of subjects requiring implantable cardioverter-defibrilators (ICDs) (Priori et al., 2002). In severe cases of CPVT, the nondihydropyridine $\mathrm{Ca}^{2+}$ channels blockers may also be effective (Swan et al., 2005; Rosso et al., 2007).

Dantrolene, a drug used to prevent malignant hyperthermia in patients with mutations in RyR1 who have been exposed to volatile anaesthetics, has been proposed to have therapeutic potential in heart disease by causing "rezipping" of the amino and central domains of RyR2 (Kobayashi et al., 2009; Kobayashi et al., 2010).

More recently, a protective effect of flecainide was proposed for CPVT treatment, thus this drug is able to block Ca2+ leak from RyR2 in CASQ2 deficient mice (Watanabe et al., 2009).

Finally, the use of drugs (JTV519) with selective action on FKBP 12.6 is still remaining in discrepancy, because diverging data to this respect were obtained.

\section{Arrhythmogenic right ventricular dysplasia}

Arrhythmogenic right ventricular dysplasia (ARVD) is a genetic form of cardiomyopathy that by contrast to CPVT, primarily affects the right ventricle (RV) and is characterized by 
the abnormal replacement of myocytes by adipose and fibrous tissue (Basso et al., 2009). The estimated prevalence of ARVD in general population ranges from 1 in 2000 to 1 in 5000 (Corrado et al., 1997) and is more frequent in men than in women, being a major cause of sudden death in the young and in athletes.

ARVD was initially believed to be a developmental defect of the RV myocardium, leading to the original designation of dysplasia (Basso et al., 1996). The diagnostic of ARVD patients including MRI, echocardiography, electrocardiography and right ventricle biopsy (McKenna et al., 1994). ARVD is characterized by functional abnormalities of the right ventricle, with abnormal depolarization/repolarization, leading to syncope, ventricular arrhythmias and sudden death (Rossi et al., 1982). Interestingly, in a high percent of patients left ventricular dysfunction was found (Corrado et al., 1997).The most typical clinical presentation of ARVD is symptomatic ventricular arrhythmias of right ventricular origin, usually triggered by effort.

ARVD can be inherited as an autosomal dominant disease with reduced penetrance and variable expression, although autosomal recessive forms also have been detected (Rampazzo et al., 2002). Mutations in genes encoding for different molecules have been linked to ARVD. To this regard, mutations in adhesion proteins (plakoglobin, desmoplakin, plakophilin-2 and desmoglein-2), in cytokines (Transforming grow factor beta 3), in transmembrane protein 43 and in RyR2 have been detected in ARVD subjects (Tiso et al., 2001; Rampazzo et al., 2002; Gerull et al., 2004; Beffagna et al., 2005; Pilichou et al., 2006; Merner et al., 2008).

Regarding RyR2 mutations, ARVD patients with mutations in RyR2 tend to have mild ARVD symptoms and are classified as ARVD2. The R176Q mutation has been associated with the ARVD disease and also carries out a second mutation of T2504M (Tiso et al., 2001). Both mutations induced the increased RyR activity in vitro (Thomas et al., 2004).

The mice model that harbors R176Q mutation allowed for the better understanding of this arrhythmogenic disease. Hearts from R176Q heterozygous mice were structurally normal, but under $\beta$-adrenergic stimulation, myocytes elicited oscillatory $\mathrm{Ca}^{2+}$ signals, leading to mice VT (Kannankeril et al., 2006).

\subsection{Treatment of ARVD}

There is not a curative treatment, instead, the aim is to detect patients with high risk and prevent complications.

The four therapeutic options are pharmacological agents (first choice), catheter ablation (if the patient is refractory to drug treatment or the disease is localized), implantable cardioverter-defibrillators (in refractory subject at risk for sudden death) and surgery as the last option (ventriculotomy and disconnection of the RV free wall) or cardiac transplantation (if severe terminal heart failure) (McKenna et al., 1994).

As we mentioned, the first option for ARVD patients is the pharmacological treatment, including ACEI, anticoagulants, antiarrhythmic agents as sotalol, verapamil, beta-blockers, amiodarone and flecainide.

In conclusion, genetic analysis is essential in both CPVT and ARVD patients, because if a pathogenic mutation is identified, a pre-symptomatic diagnosis of the disease among family 
members might be provided and also the development of the disease can be monitored to assess the risk of transmitting them offspring.

\section{References}

Ai X, Curran JW, Shannon TR, Bers DM \& Pogwizd SM. (2005). $\mathrm{Ca}^{2+} /$ calmodulin-dependent protein kinase modulates cardiac ryanodine receptor phosphorylation and sarcoplasmic reticulum $\mathrm{Ca}^{2+}$ leak in heart failure. Circ Res 97, 1314-1322.

Basso C, Corrado D, Marcus FI, Nava A \& Thiene G. (2009). Arrhythmogenic right ventricular cardiomyopathy. Lancet 373, 1289-1300.

Basso C, Thiene G, Corrado D, Angelini A, Nava A \& Valente M. (1996). Arrhythmogenic right ventricular cardiomyopathy. Dysplasia, dystrophy, or myocarditis? Circulation 94, 983-991.

Beard NA, Laver DR \& Dulhunty AF. (2004). Calsequestrin and the calcium release channel of skeletal and cardiac muscle. Prog Biophys Mol Biol 85, 33-69.

Beffagna G, Occhi G, Nava A, Vitiello L, Ditadi A, Basso C, Bauce B, Carraro G, Thiene G, Towbin JA, Danieli GA \& Rampazzo A. (2005). Regulatory mutations in transforming growth factor-beta3 gene cause arrhythmogenic right ventricular cardiomyopathy type 1 . Cardiovasc Res 65, 366-373.

Belevych AE, Terentyev D, Viatchenko-Karpinski S, Terentyeva R, Sridhar A, Nishijima Y, Wilson LD, Cardounel AJ, Laurita KR, Carnes CA, Billman GE \& Gyorke S. (2009). Redox modification of ryanodine receptors underlies calcium alternans in a canine model of sudden cardiac death. Cardiovasc Res 84, 387-395.

Benitah JP KB, Vassort G, Richard S, Gómez AM. (2002). Altered communication between Ltype calcium channels and ryanodine receptors in heart failure. Front Biosci 7, e263275.

Berlin JR, Cannell MB \& Lederer WJ. (1989). Cellular origins of the transient inward current in cardiac myocytes. Role of fluctuations and waves of elevated intracellular calcium. Circ Res 65, 115-126.

Bers DM. (2002). Cardiac excitation-contraction coupling. Nature 415, 198-205.

Blayney LM, Jones JL, Griffiths J \& Lai FA. (2010). A mechanism of ryanodine receptor modulation byFKBP12/12.6, protein kinase A, and K201. Cardiovasc Res 85, 68-78.

Cerrone M, Colombi B, Santoro M, di Barletta MR, Scelsi M, Villani L, Napolitano C \& Priori SG. (2005). Bidirectional ventricular tachycardia and fibrillation elicited in a knockin mouse model carrier of a mutation in the cardiac ryanodine receptor. Circ Res 96, e77-82.

Cerrone M NS, Tolkacheva EG, Talkachou A, O'Connell R, Berenfeld O, Anumonwo J, Pandit SV, Vikstrom K, Napolitano C, Priori SG, Jalife J. (2007). Arrhythmogenic mechanisms in a mouse model of catecholaminergic polymorphic ventricular tachycardia. Circ Res 101, 1039-1048.

Corrado D, Basso C, Thiene G, McKenna WJ, Davies MJ, Fontaliran F, Nava A, Silvestri F, Blomstrom-Lundqvist C, Wlodarska EK, Fontaine G \& Camerini F. (1997). Spectrum of clinicopathologic manifestations of arrhythmogenic right ventricular cardiomyopathy/dysplasia: a multicenter study. J Am Coll Cardiol 30, 1512-1520.

Coumel P. (1997). Polymorphous ventricular tachyarrhythmias in the absence of structural heart disease. Pacing Clin Electrophysiol 20, 2065-2067. 
Curran J, Brown KH, Santiago DJ, Pogwizd S, Bers DM \& Shannon TR. (2010). Spontaneous $\mathrm{Ca}$ waves in ventricular myocytes from failing hearts depend on $\mathrm{Ca}(2+)-$ calmodulin-dependent protein kinase II. J Mol Cell Cardiol 49, 25-32.

d'Amati G, Bagattin, A., Bauce, B., Rampazzo, A., Autore, C., Basso, C., \& King K, Romeo, M.D., Gallo, P., Thiene, G. Danieli GA, Nava A. . (2005). Juvenile sudden death in a family with polymorphic ventricular arrhythmias caused by a novel RyR2 gene mutation: evidence of specific morphological substrates. Hum Pathol 36, 761-767.

di Barletta MR, Viatchenko-Karpinski S, Nori A, Memmi M, Terentyev D, Turcato F, Valle G, Rizzi N, Napolitano C, Gyorke S, Volpe P \& Priori SG. (2006). Clinical phenotype and functional characterization of CASQ2 mutations associated with catecholaminergic polymorphic ventricular tachycardia. Circulation 114, 1012-1019.

Dirksen RT, \& Avila, G. (2002). Altered ryanodine receptor function in central core disease: leaky or uncoupled $\mathrm{Ca}(2+)$ release channels? Trends Cardiovasc Med 12, 189-197.

Dirksen WP, Lacombe VA, Chi M, Kalyanasundaram A, Viatchenko-Karpinski S, Terentyev D, Zhou Z, Vedamoorthyrao S, Li N, Chiamvimonvat N, Carnes CA, FranziniArmstrong C, Gyorke S \& Periasamy M. (2007). A mutation in calsequestrin, CASQ2D307H, impairs Sarcoplasmic Reticulum Ca2+ handling and causes complex ventricular arrhythmias in mice. Cardiovasc Res 75, 69-78.

Eldar M, Pras E \& Lahat H. (2003). A missense mutation in the CASQ2 gene is associated with autosomalrecessive catecholamine-induced polymorphic ventricular tachycardia. Trends Cardiovasc Med 13, 148-151.

Fabiato A. (1983). Calcium-induced release of calcium from the cardiac sarcoplasmic reticulum. Am J Physiol 245, C1-14.

Fauconnier J, Thireau J, Reiken S, Cassan C, Richard S, Matecki S, Marks AR \& Lacampagne A. (2010). Leaky RyR2 trigger ventricular arrhythmias in Duchenne muscular dystrophy. Proc Natl Acad Sci U S A 107, 1559-1564.

Fedida D OP, Hesketh JC, Ezrin AM. (2006). The role of late I and antiarrhythmic drugs in EAD formation and termination in Purkinje fibers. J Cardiovasc Electrophysiol Suppl 1, S71-S78.

Fernandez-Velasco M, Rueda A, Rizzi N, Benitah JP, Colombi B, Napolitano C, Priori SG, Richard S \& Gomez AM. (2009). Increased Ca2+ Sensitivity of the Ryanodine Receptor Mutant RyR2R4496C Underlies Catecholaminergic Polymorphic Ventricular Tachycardia. Circ Res 104, 201-209.

Gellen B, Fernandez-Velasco M, Briec F, Vinet L, LeQuang K, Rouet-Benzineb P, Benitah JP, Pezet M, Palais G, Pellegrin N, Zhang A, Perrier R, Escoubet B, Marniquet X, Richard S, Jaisser F, Gómez AM, Charpentier F \& Mercadier JJ. (2008). Conditional FKBP12.6 overexpression in mouse cardiac myocytes prevents triggered ventricular tachycardia through specific alterations in excitation-contraction coupling. Circulation 117, 1778-1786.

George CH, Higgs GV \& Lai FA. (2003). Ryanodine receptor mutations associated with stress-induced ventricular tachycardia mediate increased calcium release in stimulated cardiomyocytes. Circ Res 93, 531-540.

George CH JH, Thomas NL, Fry DL, Lai FA. (2007). Ryanodine receptors and ventricular arrhythmias: Emerging trends in mutations, mechanisms and therapies. J Mol and Cell Cardiol 42, 34-50.

George CH, Thomas NL, FA. L (2005) Ryanodine receptor dysfunction in arrhythmia and sudden cardiac death. Future Cardiol 1:531-541 
George CH. JH, Walters N, Thomas NL, West RR, \& Lai FA. (2006). Arrhythmogenic mutation-linked defects in ryanodine receptor autoregulation reveal a novel mechanism of $\mathrm{Ca}^{2+}$ release channel dysfunction. Circ Res 98, 88-97.

Gerull B, Heuser A, Wichter T, Paul M, Basson CT, McDermott DA, Lerman BB, Markowitz SM, Ellinor PT, MacRae CA, Peters S, Grossmann KS, Drenckhahn J, Michely B, Sasse-Klaassen S, Birchmeier W, Dietz R, Breithardt G, Schulze-Bahr E \& Thierfelder L. (2004). Mutations in the desmosomal protein plakophilin-2 are common in arrhythmogenic right ventricular cardiomyopathy. Nat Genet 36, $1162-$ 1164.

Gomez AM, Rueda A, Sainte-Marie Y, Pereira L, Zissimopoulos S, Zhu X, Schaub R, Perrier E, Perrier R, Latouche C, Richard S, Picot MC, Jaisser F, Lai FA, Valdivia HH \& Benitah JP. (2009). Mineralocorticoid Modulation of Cardiac Ryanodine Receptor Activity Is Associated With Downregulation of FK506- Binding Proteins. Circulation 119, 2179-U2189.

Gómez AM, Valdivia HH, Cheng H, Lederer MR, Santana LF, Cannell MB, McCune SA, Altschuld RA \& Lederer WJ. (1997). Defective excitation-contraction coupling in experimental cardiac hypertrophy and heart failure. Science 276, 800-806.

Gonzalez DR, Beigi F, Treuer AV \& Hare JM. (2007). Deficient ryanodine receptor Snitrosylation increases sarcoplasmic reticulum calcium leak and arrhythmogenesis in cardiomyocytes. Proc Natl Acad Sci U S A 104, 20612-20617.

Gonzalez DR, Treuer AV, Castellanos J, Dulce RA \& Hare JM. (2010). Impaired Snitrosylation of the ryanodine receptor caused by xanthine oxidase activity contributes to calcium leak in heart failure. J Biol Chem 285, 28938-28945.

Gough WB e-SN. (1989). Dependence of delayed afterdepolarizations on diastolic potentials in ischemic Purkinje fibers. Am J Physiol 257, H770-777.

GR. F. (1980). Effects of transmembrane potential on oscillatory afterpotentials induced by acetylstrophanthidin in canine ventricular tissues. J Pharmacol Exp Ther 215, 332341.

Guo T, Cornea RL, Huke S, Camors E, Yang Y, Picht E, Fruen BR \& Bers DM. (2010). Kinetics of FKBP12.6 binding to ryanodine receptors in permeabilized cardiac myocytes and effects on Ca sparks. Circ Res 106, 1743-1752.

Gyorke I, Hester N, Jones LR \& Gyorke S. (2004). The role of calsequestrin, triadin, and junctin in conferring cardiac ryanodine receptor responsiveness to luminal calcium. Biophys J 86, 2121-2128.

Gyorke S \& Terentyev D. (2008). Modulation of ryanodine receptor by luminal calcium and accessory proteins in health and cardiac disease. Cardiovasc Res 77, 245-255.

Harzheim D, Movassagh M, Foo RS, Ritter O, Tashfeen A, Conway SJ, Bootman MD \& Roderick HL. (2009). Increased InsP3Rs in the junctional sarcoplasmic reticulum augment $\mathrm{Ca}^{2+}$ transients and arrhythmias associated with cardiac hypertrophy. Proc Natl Acad Sci U S A 106, 11406-11411.

Herron TJ MM, Anumonwo J, et al. (2010). Purkinje cell calcium dysregulation is the cellular mechanism that underlies catecholaminergic polymorphic ventricular tachycardia. Heart Rhythm 7, 1122-1128.

Huang F, Shan J, Reiken S, Wehrens XH \& Marks AR. (2006). Analysis of calstabin2 (FKBP12.6)-ryanodine receptor interactions: rescue of heart failure by calstabin2 in mice. Proc Natl Acad Sci U S A 103, 3456-3461.

Ikemoto N \& Yamamoto T. (2000). Postulated role of inter-domain interaction within the ryanodine receptor in $\mathrm{Ca}(2+)$ channel regulation. Trends Cardiovasc Med 10, 310-316. 
Ikemoto N \& Yamamoto T. (2002). Regulation of calcium release by interdomain interaction within ryanodine receptors. Front Biosci 7, d671-683.

Jiang D CW, Wang R, Zhang L, Chen SR. (2007). Loss of luminal Ca ${ }^{2+}$ activation in the cardiac ryanodine receptor is associated with ventricular fibrillation and sudden death. Proc Natl Acad Sci U S A 104, 18309-18314.

Jiang D JP, Davis DR, Gow R, Green MS, Birnie DH, Chen SR, Gollob MH. (2010). Characterization of a novel mutation in the cardiac ryanodine receptor that results in catecholaminergic polymorphic ventricular tachycardia. Channels (Austin) 4(4), 302-310.

Jiang D XB, Yang D, Wang R, Choi P, Zhang L, Cheng H, Chen SR. (2004). RyR2 mutations linked to ventricular tachycardia and sudden death reduce the threshold for storeoverload-induced $\mathrm{Ca}^{2+}$ release (SOICR). Proc Natl Acad Sci U S A 101, 13062-13067.

Jiang D XB, Zhang L, Chen SR. (2005). Enhanced basal activity of a cardiac $\mathrm{Ca}^{2+}$ release channel (ryanodine receptor) mutant associated with ventricular tachycardia and sudden death. Circ Res 97, 1173-1181.

Jiang D, Xiao B, Yang D, Wang R, Choi P, Zhang L, Cheng H \& Chen SR. (2004). RyR2 mutations linked to ventricular tachycardia and sudden death reduce the threshold for store-overload-induced Ca2+ release (SOICR). Proc Natl Acad Sci U S A 101, 13062-13067.

Jiang MT, Lokuta AJ, Farrell EF, Wolff MR, Haworth RA \& Valdivia HH. (2002). Abnormal $\mathrm{Ca}^{2+}$ release, but normal ryanodine receptors, in canine and human heart failure. Circ Res 91, 1015-1022.

Kang G GS, Liu N, Liu FY, Zhang J, Priori SG, Fishman GI. (2010). Purkinje cells from RyR2 mutant mice are highly arrhythmogenic but responsive to targeted therapy. Circ Res 107, 512-519.

Kannankeril PJ, Mitchell BM, Goonasekera SA, Chelu MG, Zhang W, Sood S, Kearney DL, Danila CI, De Biasi M, Wehrens XH, Pautler RG, Roden DM, Taffet GE, Dirksen RT, Anderson ME \& Hamilton SL. (2006). Mice with the R176Q cardiac ryanodine receptor mutation exhibit catecholamine-induced ventricular tachycardia and cardiomyopathy. Proc Natl Acad Sci U S A 103, 12179-12184.

Kazemian P GM, Pantano A, Oudit GY. (2011). A Novel Mutation in the RYR2 Gene Leading to Catecholaminergic Polymorphic Ventricular Tachycardia and Paroxysmal Atrial Fibrillation: Dose- Dependent Arrhythmia-Event Suppression by $\beta$-Blocker Therapy. Can J Cardiol In press.

Keller M, Kao JP, Egger M \& Niggli E. (2007). Calcium waves driven by "sensitization" wave-fronts. Cardiovasc Res 74, 39-45.

Kim E, Youn B, Kemper L, Campbell C, Milting H, Varsanyi M \& Kang C. (2007). Characterization of human cardiac calsequestrin and its deleterious mutants. J Mol Biol 373, 1047-1057.

Knollmann BC. (2009). New roles of calsequestrin and triadin in cardiac muscle. J Physiol 587, 3081-3087.

Knollmann BC, Chopra N, Hlaing T, Akin B, Yang T, Ettensohn K, Knollmann BE, Horton KD, Weissman NJ, Holinstat I, Zhang W, Roden DM, Jones LR, Franzini-Armstrong C \& Pfeifer K. (2006). Casq2 deletion causes sarcoplasmic reticulum volume increase, premature $\mathrm{Ca}^{2+}$ release, and catecholaminergic polymorphic ventricular tachycardia. J Clin Invest 116, 2510-2520.

Kobayashi S, Yano M, Suetomi T, Ono M, Tateishi H, Mochizuki M, Xu X, Uchinoumi H, Okuda S, Yamamoto T, Koseki N, Kyushiki H, Ikemoto N \& Matsuzaki M. (2009). 
Dantrolene, a therapeutic agent for malignant hyperthermia, markedly improves the function of failing cardiomyocytes by stabilizing interdomain interactions within the ryanodine receptor. J Am Coll Cardiol 53, 1993-2005.

Kobayashi S, Yano M, Uchinoumi H, Suetomi T, Susa T, Ono M, Xu X, Tateishi H, Oda T, Okuda S, Doi M, Yamamoto T \& Matsuzaki M. (2010). Dantrolene, a therapeutic agent for malignant hyperthermia, inhibits catecholaminergic polymorphic ventricular tachycardia in a RyR2(R2474S/+) knock-in mouse model. Circ J 74, 2579-2584.

Koop AG, Petra; Chen, S. R. Wayne; Thieleczek, Rolf; Varsanyi, Magdolna . . (2008). ARVCRelated Mutations in Divergent Region 3 Alter Functional Properties of the Cardiac Ryanodine Receptor. Biophysical J 94, 4668-4677.

Kubalova Z, Terentyev D, Viatchenko-Karpinski S, Nishijima Y, Gyorke I, Terentyeva R, da Cunha DN, Sridhar A, Feldman DS, Hamlin RL, Carnes CA \& Gyorke S. (2005). Abnormal intrastore calcium signaling in chronic heart failure. Proc Natl Acad Sci U S A 102, 14104-14109.

Lahat H, Eldar M, Levy-Nissenbaum E, Bahan T, Friedman E, Khoury A, Lorber A, Kastner DL, Goldman B \& Pras E. (2001a). Autosomal recessive catecholamine- or exerciseinduced polymorphic ventricular tachycardia: clinical features and assignment of the disease gene to chromosome 1p13-21. Circulation 103, 2822-2827.

Lahat H, Pras E, Olender T, Avidan N, Ben-Asher E, Man O, Levy-Nissenbaum E, Khoury A, Lorber A, Goldman B, Lancet D \& Eldar M. (2001b). A missense mutation in a highly conserved region of CASQ2 is associated with autosomal recessive catecholamine-induced polymorphic ventricular tachycardia in Bedouin families from Israel. Am J Hum Genet 69, 1378-1384.

Leenhardt A, Lucet V, Denjoy I, Grau F, Ngoc DD \& Coumel P. (1995). Catecholaminergic polymorphic ventricular tachycardia in children. A 7-year follow-up of 21 patients. Circulation 91, 1512-1519.

Lehnart SE, Ackerman MJ, Benson DW, Jr., Brugada R, Clancy CE, Donahue JK, George AL, Jr., Grant AO, Groft SC, January CT, Lathrop DA, Lederer WJ, Makielski JC, Mohler PJ, Moss A, Nerbonne JM, Olson TM, Przywara DA, Towbin JA, Wang LH \& Marks AR. (2007). Inherited arrhythmias: a National Heart, Lung, and Blood Institute and Office of Rare Diseases workshop consensus report about the diagnosis, phenotyping, molecular mechanisms, and therapeutic approaches for primary cardiomyopathies of gene mutations affecting ion channel function. Circulation 116, 2325-2345.

Lehnart SE, Mongillo M, Bellinger A, Lindegger N, Chen BX, Hsueh W, Reiken S, Wronska A, Drew LJ, Ward CW, Lederer WJ, Kass RS, Morley G \& Marks AR. (2008). Leaky $\mathrm{Ca}^{2+}$ release channel/ryanodine receptor 2 causes seizures and sudden cardiac death in mice. J Clin Invest 118, 2230-2245.

Lehnart SE, Wehrens XH, Laitinen PJ, Reiken SR, Deng SX, Cheng Z, Landry DW, Kontula K, Swan H \& Marks AR. (2004). Sudden death in familial polymorphic ventricular tachycardia associated with calcium release channel (ryanodine receptor) leak. Circulation 109, 3208-3214.

Liu N, Colombi B, Memmi M, Zissimopoulos S, Rizzi N, Negri S, Imbriani M, Napolitano C, Lai FA \& Priori SG. (2006). Arrhythmogenesis in catecholaminergic polymorphic ventricular tachycardia: insights from a RyR2 R4496C knock-in mouse model. Circ Res 99, 292-298. 
Lobo PA \& Van Petegem F. (2009). Crystal structures of the N-terminal domains of cardiac and skeletal muscle ryanodine receptors: insights into disease mutations. Structure $17,1505-1514$.

Loyer X, Gomez AM, Milliez P, Fernandez-Velasco M, Vangheluwe P, Vinet L, Charue D, Vaudin E, Zhang W, Sainte-Marie Y, Robidel E, Marty I, Mayer B, Jaisser F, Mercadier JJ, Richard S, Shah AM, Benitah JP, Samuel JL \& Heymes C. (2008). Cardiomyocyte overexpression of neuronal nitric oxide synthase delays transition toward heart failure in response to pressure overload by preserving calcium cycling. Circulation 117, 3187-3198.

Maier LS, Zhang T, Chen L, DeSantiago J, Brown JH \& Bers DM. (2003). Transgenic CaMKIIdeltaC overexpression uniquely alters cardiac myocyte $\mathrm{Ca}^{2+}$ handling: reduced SR Ca ${ }^{2+}$ load and activated SR Ca ${ }^{2+}$ release. Circ Res 92, 904-911.

Makarand Deo PMB, Albert M. Kim and Edward J. Vigmond. (2010). Arrhythmogenesis by single ectopic beats originating in the Purkinje system. Am J Physiol Heart Circ Physiol 299, H1002-H1011.

Marks AR. (2001). Ryanodine receptors/calcium release channels in heart failure and sudden cardiac death. J Mol Cell Cardiol 33, 615-624.

Marx SO, Reiken S, Hisamatsu Y, Jayaraman T, Burkhoff D, Rosemblit N \& Marks AR. (2000). PKA phosphorylation dissociates FKBP12.6 from the calcium release channel (ryanodine receptor): defective regulation in failing hearts. Cell 101, 365376.

Marx SO RS, Hisamatsu Y, Jayaraman T, Burkhoff D, Rosemblit N, Marks AR. (2000). PKA phosphorylation dissociates FKBP12.6 from the calcium release channel (ryanodine receptor): defective regulation in failing hearts. Cell 101, 365-376.

McKenna WJ, Thiene G, Nava A, Fontaliran F, Blomstrom-Lundqvist C, Fontaine G \& Camerini F. (1994). Diagnosis of arrhythmogenic right ventricular dysplasia/cardiomyopathy. Task Force of the Working Group Myocardial and Pericardial Disease of the European Society of Cardiology and of the Scientific Council on Cardiomyopathies of the International Society and Federation of Cardiology. Br Heart J 71, 215-218.

Medeiros-Domingo A BZ, Tester DJ, et al. . (2009). The RYR2-encoded ryanodine receptor/calcium release channel in patients diagnosed previously with either catecholaminergic polymorphic ventricular tachycardia or genotype negative, exercise-induced long QT syndrome: a comprehensive open reading frame mutational analysis. . J Am Coll Cardiol 54, 2065-2074.

Meli ACR, Marwan M.; Dura,Miroslav; Reiken, Steven; Wronska,Anetta; Wojciak, Julianne; Carroll, Joan; Scheinman, Melvin M.; Marks Andrew R. . (2011). A Novel Ryanodine Receptor Mutation Linked to Sudden Death Increases Sensitivity to Cytosolic Calcium. Circ Res published online Jun 9.

Merner ND, Hodgkinson KA, Haywood AF, Connors S, French VM, Drenckhahn JD, Kupprion C, Ramadanova K, Thierfelder L, McKenna W, Gallagher B, MorrisLarkin L, Bassett AS, Parfrey PS \& Young TL. (2008). Arrhythmogenic right ventricular cardiomyopathy type 5 is a fully penetrant, lethal arrhythmic disorder caused by a missense mutation in the TMEM43 gene. Am J Hum Genet 82, 809-821.

Mohamed U, Napolitano C \& Priori SG. (2007). Molecular and electrophysiological bases of catecholaminergic polymorphic ventricular tachycardia. J Cardiovasc Electrophysiol 18, 791-797. 
Nakajima T, Kaneko Y, Taniguchi Y, Hayashi K, Takizawa T, Suzuki T \& Nagai R. (1997). The mechanism of catecholaminergic polymorphic ventricular tachycardia may be triggered activity due to delayed afterdepolarization. Eur Heart J 18, 530-531.

Napolitano C \& Priori SG. (2007). Diagnosis and treatment of catecholaminergic polymorphic ventricular tachycardia. Heart Rhythm 4, 675-678.

Oda T, Yano M, Yamamoto T, Tokuhisa T, Okuda S, Doi M, Ohkusa T, Ikeda Y, Kobayashi S, Ikemoto N \& Matsuzaki M. (2005). Defective regulation of interdomain interactions within the ryanodine receptor plays a key role in the pathogenesis of heart failure. Circulation 111, 3400-3410.

Pilichou K, Nava A, Basso C, Beffagna G, Bauce B, Lorenzon A, Frigo G, Vettori A, Valente M, Towbin J, Thiene G, Danieli GA \& Rampazzo A. (2006). Mutations in desmoglein-2 gene are associated with arrhythmogenic right ventricular cardiomyopathy. Circulation 113, 1171-1179.

Pizzale S, Gollob MH, Gow R \& Birnie DH. (2008). Sudden death in a young man with catecholaminergic polymorphic ventricular tachycardia and paroxysmal atrial fibrillation. J Cardiovasc Electrophysiol 19, 1319-1321.

Postma AV, Denjoy I, Hoorntje TM, Lupoglazoff JM, Da Costa A, Sebillon P, Mannens MM, Wilde AA \& Guicheney P. (2002). Absence of calsequestrin 2 causes severe forms of catecholaminergic polymorphic ventricular tachycardia. Circ Res 91, e21-26.

Postma AV, Denjoy I, Kamblock J, Alders M, Lupoglazoff JM, Vaksmann G, Dubosq-Bidot L, Sebillon P, Mannens MM, Guicheney P \& Wilde AA. (2005). Catecholaminergic polymorphic ventricular tachycardia: RYR2 mutations, bradycardia, and follow up of the patients. J Med Genet 42, 863-870.

Priori SG AE, Blømstrom-Lundqvist C, Bossaert L, Breithardt G, Brugada P, Camm JA, Cappato R, Cobbe SM, Di MC, Maron BJ, McKenna WJ, Pedersen AK, Ravens U, Schwartz PJ, Trusz-Gluza M, Vardas P, Wellens HJ, Zipes DP. (2002). Task Force on Sudden Cardiac Death, European Society of Cardiology. Europace 4, 3-18.

Priori SG, Napolitano C, Memmi M, Colombi B, Drago F, Gasparini M, DeSimone L, Coltorti F, Bloise R, Keegan R, Cruz Filho FE, Vignati G, Benatar A \& DeLogu A. (2002). Clinical and molecular characterization of patients with catecholaminergic polymorphic ventricular tachycardia. Circulation 106, 69-74.

Priori SG NC, Tiso N, Memmi M, Vignati G, Bloise R, Sorrentino V, Danieli GA. (2001). Mutations in the cardiac ryanodine receptor gene (hRyR2) underlie catecholaminergic polymorphic ventricular tachycardia. Circulation 103, 196-200.

Qin J, Valle G, Nani A, Nori A, Rizzi N, Priori SG, Volpe P \& Fill M. (2008). Luminal Ca ${ }^{2+}$ regulation of single cardiac ryanodine receptors: insights provided by calsequestrin and its mutants. J Gen Physiol 131, 325-334.

Rampazzo A, Nava A, Malacrida S, Beffagna G, Bauce B, Rossi V, Zimbello R, Simionati B, Basso C, Thiene G, Towbin JA \& Danieli GA. (2002). Mutation in human desmoplakin domain binding to plakoglobin causes a dominant form of arrhythmogenic right ventricular cardiomyopathy. Am J Hum Genet 71, 1200-1206.

Reiken S, Gaburjakova M, Gaburjakova J, He Kl KL, Prieto A, Becker E, Yi Gh GH, Wang J, Burkhoff D \& Marks AR. (2001). beta-adrenergic receptor blockers restore cardiac calcium release channel (ryanodine receptor) structure and function in heart failure. Circulation 104, 2843-2848.

Reiken S, Gaburjakova M, Guatimosim S, Gómez AM, D'Armiento J, Burkhoff D, Wang J, Vassort G, Lederer WJ \& Marks AR. (2003). Protein kinase A phosphorylation of the 
cardiac calcium release channel (ryanodine receptor) in normal and failing hearts. Role of phosphatases and response to isoproterenol. J Biol Chem 278, 444-453.

Rosen MR \& Danilo P, Jr. (1980). Effects of tetrodotoxin, lidocaine, verapamil, and AHR2666 on Ouabain-induced delayed afterdepolarizations in canine Purkinje fibers. Circ Res 46, 117-124.

Rossi P, Massumi A, Gillette P \& Hall RJ. (1982). Arrhythmogenic right ventricular dysplasia: clinical features, diagnostic techniques, and current management. Am Heart J 103, 415-420.

Rosso R, Kalman JM, Rogowski O, Diamant S, Birger A, Biner S, Belhassen B \& Viskin S. (2007). Calcium channel blockers and beta-blockers versus beta-blockers alone for preventing exercise-induced arrhythmias in catecholaminergic polymorphic ventricular tachycardia. Heart Rhythm 4, 1149-1154.

Shou W, Aghdasi B, Armstrong DL, Guo Q, Bao S, Charng MJ, Mathews LM, Schneider MD, Hamilton SL \& Matzuk MM. (1998). Cardiac defects and altered ryanodine receptor function in mice lacking FKBP12. Nature 391, 489-492.

Song L, Alcalai R, Arad M, Wolf CM, Toka O, Conner DA, Berul CI, Eldar M, Seidman CE \& Seidman JG. (2007). Calsequestrin 2 (CASQ2) mutations increase expression of calreticulin and ryanodine receptors, causing catecholaminergic polymorphic ventricular tachycardia. J Clin Invest 117, 1814-1823.

Sumitomo N, Harada K, Nagashima M, Yasuda T, Nakamura Y, Aragaki Y, Saito A, Kurosaki K, Jouo K, Koujiro M, Konishi S, Matsuoka S, Oono T, Hayakawa S, Miura M, Ushinohama H, Shibata T \& Niimura I. (2003). Catecholaminergic polymorphic ventricular tachycardia: electrocardiographic characteristics and optimal therapeutic strategies to prevent sudden death. Heart 89, 66-70.

Sumitomo N, Sakurada H, Taniguchi K, Matsumura M, Abe O, Miyashita M, Kanamaru H, Karasawa K, Ayusawa M, Fukamizu S, Nagaoka I, Horie M, Harada K \& Hiraoka M. (2007). Association of atrial arrhythmia and sinus node dysfunction in patients with catecholaminergic polymorphic ventricular tachycardia. Circ J 71, 1606-1609.

Swan H, Laitinen P, Kontula K \& Toivonen L. (2005). Calcium channel antagonism reduces exercise-induced ventricular arrhythmias in catecholaminergic polymorphic ventricular tachycardia patients with RyR2 mutations. J Cardiovasc Electrophysiol 16, 162-166.

Sy RW GM, Klein GJ, Yee R, Skanes AC, Gula LJ, Leong-Sit P, Gow RM, Green MS, Birnie DH, Krahn AD. (2011). Arrhythmia characterization and long-term outcomes in catecholaminergic polymorphic ventricular tachycardia. Heart Rhythm 8, 864-871.

Tateishi H, Yano M, Mochizuki M, Suetomi T, Ono M, Xu X, Uchinoumi H, Okuda S, Oda T, Kobayashi S, Yamamoto T, Ikeda Y, Ohkusa T, Ikemoto N \& Matsuzaki M. (2009). Defective domain-domain interactions within the ryanodine receptor as a critical cause of diastolic $\mathrm{Ca}^{2+}$ leak in failing hearts. Cardiovasc Res 81, 536-545.

Terentyev D, Kubalova Z, Valle G, Nori A, Vedamoorthyrao S, Terentyeva R, ViatchenkoKarpinski S, Bers DM, Williams SC, Volpe P \& Gyorke S. (2008). Modulation of SR Ca release by luminal $\mathrm{Ca}$ and calsequestrin in cardiac myocytes: effects of CASQ2 mutations linked to sudden cardiac death. Biophys J 95, 2037-2048.

Terentyev D, Nori A, Santoro M, Viatchenko-Karpinski S, Kubalova Z, Gyorke I, Terentyeva R, Vedamoorthyrao S, Blom NA, Valle G, Napolitano C, Williams SC, Volpe P, Priori SG \& Gyorke S. (2006). Abnormal interactions of calsequestrin with the ryanodine receptor calcium release channel complex linked to exercise-induced sudden cardiac death. Circ Res 98, 1151-1158. 
Terentyev D, Viatchenko-Karpinski S, Gyorke I, Volpe P, Williams SC \& Gyorke S. (2003). Calsequestrin determines the functional size and stability of cardiac intracellular calcium stores: Mechanism for hereditary arrhythmia. Proc Natl Acad Sci U S A 100, 11759-11764.

Terentyev D, Viatchenko-Karpinski S, Vedamoorthyrao S, Oduru S, Gyorke I, Williams SC \& Gyorke S. (2007). Protein protein interactions between triadin and calsequestrin are involved in modulation of sarcoplasmic reticulum calcium release in cardiac myocytes. J Physiol 583, 71-80.

Tester DJ KL, Will ML, Ackerman MJ. (2005). Spectrum and prevalence of cardiac ryanodine receptor (RyR2) mutations in a cohort of unrelated patients referred explicitly for long QT syndrome genetic testing. Heart Rhythm 2, 1099-1105.

Tester DJ D, Miroslav; Carturan, Elisa; Reiken, Steven; Wronska, Anetta; Marks, Andrew R.; Ackerman, Michael J. (2007). A mechanism for sudden infant death syndrome (SIDS): Stress-induced leak via ryanodine receptors Heart Rhythm 4, 733-739

Thomas NL, George CH \& Lai FA. (2004). Functional heterogeneity of ryanodine receptor mutations associated with sudden cardiac death. Cardiovasc Res 64, 52-60.

Thomas NL, Lai, F.A., George, C.H. . (2005). Differential Ca ${ }^{2+}$ sensitivity of RyR2 mutations reveals distinct mechanisms of channel dysfunction in sudden cardiac death Biochem Biophys Res Commun, 231-238

Tiso N, Salamon M, Bagattin A, Danieli GA, Argenton F \& Bortolussi M. (2002). The binding of the RyR2 calcium channel to its gating protein FKBP12.6 is oppositely affected by ARVD2 and VTSIP mutations. Biochem Biophys Res Commun 299, 594-598.

Tiso N, Stephan DA, Nava A, Bagattin A, Devaney JM, Stanchi F, Larderet G, Brahmbhatt B, Brown K, Bauce B, Muriago M, Basso C, Thiene G, Danieli GA \& Rampazzo A. (2001). Identification of mutations in the cardiac ryanodine receptor gene in families affected with arrhythmogenic right ventricular cardiomyopathy type 2 (ARVD2). Hum Mol Genet 10, 189-194.

Tung CC, Lobo PA, Kimlicka L \& Van Petegem F. (2010). The amino-terminal disease hotspot of ryanodine receptors forms a cytoplasmic vestibule. Nature 468, 585-588.

Uchinoumi H, Yano M, Suetomi T, Ono M, Xu X, Tateishi H, Oda T, Okuda S, Doi M, Kobayashi S, Yamamoto T, Ikeda Y, Ohkusa T, Ikemoto N \& Matsuzaki M. (1998). Catecholaminergic polymorphic ventricular tachycardia is caused by mutationlinked defective conformational regulation of the ryanodine receptor. Circ Res 106, 1413-1424.

Venetucci LA, Trafford AW, O'Neill SC \& Eisner DA. (2007). Na/Ca exchange: regulator of intracellular calcium and source of arrhythmias in the heart. Ann N Y Acad Sci 1099, 315-325.

Venetucci LA, Trafford AW, O'Neill SC \& Eisner DA. (2008). The sarcoplasmic reticulum and arrhythmogenic calcium release. Cardiovasc Res 77, 285-292.

Vyas H, Hejlik J \& Ackerman MJ. (2006). Epinephrine QT stress testing in the evaluation of congenital long-QT syndrome: diagnostic accuracy of the paradoxical QT response. Circulation 113, 1385-1392.

Wagenknecht T, R. Grassucci, J. Frank, A. Saito, M. Inui \& S. Fleischer. (1989). Three dimensional architecture of the calcium channel/foot structure of sarcoplasmic reticulum. Nature 338, 167-170.

Watanabe H, Chopra N, Laver D, Hwang HS, Davies SS, Roach DE, Duff HJ, Roden DM, Wilde AA \& Knollmann BC. (2009). Flecainide prevents catecholaminergic polymorphic ventricular tachycardia in mice and humans. Nat Med 15, 380-383. 
Wehrens XH, Lehnart SE, Huang F, Vest JA, Reiken SR, Mohler PJ, Sun J, Guatimosim S, Song LS, Rosemblit N, D'Armiento JM, Napolitano C, Memmi M, Priori SG, Lederer WJ \& Marks AR. (2003). FKBP12.6 deficiency and defective calcium release channel (ryanodine receptor) function linked to exercise induced sudden cardiac death. Cell 113, 829-840.

Wehrens XH, Lehnart SE \& Marks AR. (2005). Intracellular calcium release and cardiac disease. Annu Rev Physiol 67, 69-98.

Wehrens XH, Lehnart SE, Reiken SR, Deng SX, Vest JA, Cervantes D, Coromilas J, Landry DW \& Marks AR. (2004). Protection from cardiac arrhythmia through ryanodine receptor-stabilizing protein calstabin2. Science 304, 292-296.

Xiao J, Tian X, Jones PP, Bolstad J, Kong H, Wang R, Zhang L, Duff HJ, Gillis AM, Fleischer S, Kotlikoff M, Copello JA \& Chen SR. (2007). Removal of FKBP12.6 does not alter the conductance and activation of the cardiac ryanodine receptor or the susceptibility to stress-induced ventricular arrhythmias. J Biol Chem 282, 3482834838.

Xin HB, Senbonmatsu T, Cheng DS, Wang YX, Copello JA, Ji GJ, Collier ML, Deng KY, Jeyakumar LH, Magnuson MA, Inagami T, Kotlikoff MI \& Fleischer S. (2002). Oestrogen protects FKBP12.6 null mice from cardiac hypertrophy. Nature 416, 334338.

Yamamoto T E-HR, Ikemoto N. (2000). Postulated role of interdomain interaction within the ryanodine receptor in $\mathrm{Ca}(2+)$ channel regulation. J Biol Chem 275, 11618-11625.

Yang Z, Ikemoto, N., Lamb, G.D. and Steele, D.S. (2006). The RyR2 central domain peptide DPc10 lowers the threshold for spontaneous $\mathrm{Ca}^{2+}$ release in permeabilized cardiomyocytes Cardiovasc Res 70, 475-485.

Yano M, Okuda S, Oda T, Tokuhisa T, Tateishi H, Mochizuki M, Noma T, Doi M, Kobayashi S, Yamamoto T, Ikeda Y, Ohkusa T, Ikemoto N \& Matsuzaki M. (2005). Correction of defective interdomain interaction within ryanodine receptor by antioxidant is a new therapeutic strategy against heart failure. Circulation 112, 3633-3643.

Yano M, Ono K, Ohkusa T, Suetsugu M, Kohno M, Hisaoka T, Kobayashi S, Hisamatsu Y, Yamamoto T, Kohno M, Noguchi N, Takasawa S, Okamoto H \& Matsuzaki M. (2000). Altered stoichiometry of FKBP12.6 versus ryanodine receptor as a cause of abnormal $\mathrm{Ca}(2+)$ leak through ryanodine receptor in heart failure. Circulation 102, 2131-2136.

Yano M, Yamamoto T, Ikeda Y \& Matsuzaki M. (2006). Mechanisms of Disease: ryanodine receptor defects in heart failure and fatal arrhythmia. Nat Clin Pract Cardiovasc Med $3,43-52$. 


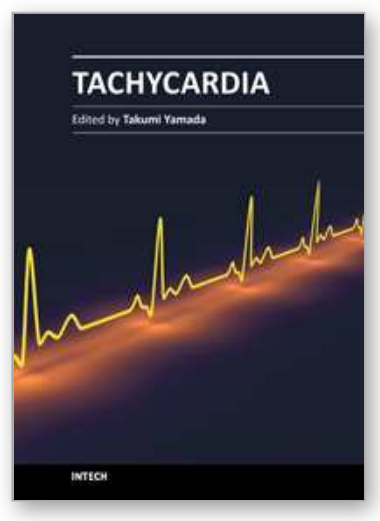

\author{
Tachycardia \\ Edited by Prof. Takumi Yamada
}

ISBN 978-953-51-0413-1

Hard cover, 202 pages

Publisher InTech

Published online 30, March, 2012

Published in print edition March, 2012

Heart rates are normally controlled by a natural pacemaker, the sinus node, and normal heart rhythm is called sinus rhythm. Tachycardia is defined as a faster heart rhythm than normal sinus rhythm. Tachycardias can cause symptoms such as palpitations, chest pain, shortness of breath and fatigue, which reduce the quality of life. Fast tachycardias can cause hemodynamic collapse and sudden cardiac death. The causes, mechanisms, and origins of tachycardias are various. The diagnosis of tachycardias is made by electrocardiograms and electrophysiological testing. Tachycardias can be managed and treated by pharmacological and nonpharmacological approaches. This book covers these concerns from basic and clinical points of view and will lead to a further understanding and improvement in the clinical outcomes of tachycardias.

\title{
How to reference
}

In order to correctly reference this scholarly work, feel free to copy and paste the following:

María Fernández-Velasco, Ana María Gómez, Jean-Pierre Benitah and Patricia Neco (2012). Ryanodine Receptor Channelopathies: The New Kid in the Arrhythmia Neighborhood, Tachycardia, Prof. Takumi Yamada (Ed.), ISBN: 978-953-51-0413-1, InTech, Available from:

http://www.intechopen.com/books/tachycardia/ryanodine-receptor-channelopathies-the-new-kid-in-thearrhythmia-neighborhood-

\section{INTECH}

open science | open minds

\author{
InTech Europe \\ University Campus STeP Ri \\ Slavka Krautzeka 83/A \\ 51000 Rijeka, Croatia \\ Phone: +385 (51) 770447 \\ Fax: +385 (51) 686166 \\ www.intechopen.com
}

\author{
InTech China \\ Unit 405, Office Block, Hotel Equatorial Shanghai \\ No.65, Yan An Road (West), Shanghai, 200040, China \\ 中国上海市延安西路65号上海国际贵都大饭店办公楼 405 单元 \\ Phone: +86-21-62489820 \\ Fax: +86-21-62489821
}


(C) 2012 The Author(s). Licensee IntechOpen. This is an open access article distributed under the terms of the Creative Commons Attribution 3.0 License, which permits unrestricted use, distribution, and reproduction in any medium, provided the original work is properly cited. 